\title{
Competitiveness and Positioning of Municipalities in the Republic of Tatarstan
}

\author{
Rubtzov V.A. \\ Kazan Federal University, Institute of Management, Economics and Finance, Kazan, 420008, Russia \\ Email:nz9nz@rambler.ru \\ Rozhko M.V
}

Kazan Federal University, Institute of Management, Economics and Finance, Kazan, 420008, Russia

Gabdrakhmanov N.K.

Kazan Federal University, Institute of Management, Economics and Finance, Kazan, 420008, Russia

Email:nz9nz@rambler.ru

Gilmanova A.A.

Kazan Federal University, Institute of Language, 420008, Kazan, Russia

\section{Doi:10.5901/mjss.2015.v6n3p761}

\section{Abstract}

Currently the competition of territories, including municipalities, for investment and innovation has increased. In this competition, the advantage is given to territories, which strive to increase their competitiveness as part of different territorial entities. The concept of competitiveness should be built on mutual balance of all principles of social and economic development. The competitiveness of the region should be examined according to the set of indices, which are the parts of subsystems: population, economy, infrastructure, ecology. The article deals with theoretic and practical issues of assessing competitiveness of municipalities in the Republic of Tatarstan. The methods of their positioning according to the system of indices, which reflect the level of their social and economic development and investment attractiveness, are offered.

Keywords: competitiveness, positioning, region, municipality, social and economic development.

\section{Introduction}

The assessment of territorial entities' competitiveness has become one of the topical issues of economic life in presentday conditions $[1,2,3,4]$. This is particularly significant in the context of intensified globalization process and the launched process of social transition to the postindustrial stage of development. Under conditions of post-industrial development of regions, the role of their positioning and competitiveness for investment, innovations and high technologies has increased. Special schools of competitiveness theory have appeared. They examine the conditions of certain countries and regions and their role in the world economic system, as well as the issues of national security protection. The issue refers to a new research area in regional economics, which is associated with the appearance of terms "cluster" and "regional cluster".

In the theory of self-organization, the concept of rank parameters takes significant place. These parameters are the most important variables of the complex system, which becomes the most essential in the process of self-organization. They gradually begin to determine the movement of other variables of the system. In this context, the theoretical justification of territorial entities' competitiveness suggests the assessment of the following: firstly, the objective long-term factors; secondly, the actual economic situation; thirdly, prerequisites of their social and economic development. Taking into account these factors helps to formulate the system of territorial entities' competitiveness indices in a new way and rank its main parameters.

It is more rational to examine the competitiveness of territorial economic system in terms of such significant parameters as population, economics, infrastructure and ecology. It is quite certain that the main goal of every concept connected with territorial entity's development, the positioning and assessment of competitiveness should be associated 
with better living conditions, which can be guaranteed by sustainable economic growth, rise in population's real income, the increase of investment volume into the economy and improvement of social service quality [7, 8, 9]. Also, additional parameters could be taken into account $[10,11,12]$.

The assessment and positioning can be carried out from the perspective of economic and geographical zoning on different levels - of certain countries, regions and smaller territorial systems. The assessment of competitiveness and positioning of municipalities as parts of regions seem interesting and practically valuable.

\section{Method}

In the work devoted to competitiveness of the Republic of Tatarstan we developed the scheme of issues which compose the competitiveness of the region. The following set of diagnostic indices was based on that scheme:

1. Gross Regional Product (GRP) per capita (RUB);

2. Turnover rate of organizations unrelated to exploitation of natural resources (BIn, RUB);

3. The rate of innovative activity of organizations (\%);

4. The density of transportation system ( $\mathrm{km}$ per 1000 square $\mathrm{km}$ of territory);

5. Emissions of pollutants into the atmospheric air per citizen (tn);

6. The rate of capital assets;

7. Life expectancy at birth (years);

8. Morbidity rate per 1000 of population;

9. Education level of working population ;

10. The share of population with substandard income (\%);

11. The share of population with opportunity to receive television programmes (\%);

12. Fixed asset investment per capita (RUB).

Taking this set of indices as the basis, it is possible to assess the positioning of municipalities in the Republic of Tatarstan. At the same time, we face a number of difficulties of objective character.

Firstly, the municipalities do not possess all qualities, which characterize the region.

Secondly, the collected and published statistics on municipalities is not as diverse as the corresponding data on the regions.

Therefore, the diagnostic set for analyzing municipalities should be considered. This set should be convenient for calculation as well as characterize the main aspects of social and economic development and competitiveness of a territory. In the context of municipal districts, the parameter of Gross territorial product (GTP) per capita will be applied. Apart from GTP, the following indicators from the diagnostic set can be used for evaluating the region: pollutant emissions per capita, morbidity rate per 1000 of population, fixed capital expenditure per capita. It is also appropriate to use indicators similar to those existing in the set of regional indicators in general - volume of own-produced shipped goods, the amount of self-made work and services in manufacturing industry, the density of hard surface roads, gross book value of fixed assets.

In addition to these indicators, several more parameters characterizing social and demographic sphere should be introduced into the system of assessment:

1. Infant mortality. This indicator characterizes the demographic constituent.

2. Unemployment rate. This indicator is essential, as employment of population is socially significant and is included into the number of priorities of social and economic policies.

3. Retail turnover per capita.

4. The amount of people who do regular exercises and sport. This indicator influences the competitiveness of regional system, which is impossible without the development of achievement-oriented population and is partially determined by its health and fitness level.

5. The amount of recorded offence. Crime is a socially dangerous phenomenon and therefore its high rates lower the competitiveness of a territory.

Thus, we can formulate the diagnostic set of indicators, which characterize the positioning of municipalities:

1. GTP per capita (RUB);

2. The volume of own-produced shipped goods, the amount of self-made work and services in manufacturing industry (thousand, RUB);

3. The density of hard surface roads ( $\mathrm{km}$ per square $\mathrm{km}$ of territory);

4. Pollutant emissions from stationary sources per capita $(\mathrm{kg})$;

5. Gross book value of fixed assets ( $\mathrm{mln}, \mathrm{RUB})$; 
6. Infant mortality per 1000 born alive;

7. Morbidity rate per $\mathbf{1 0 0 0}$ of population;

8. Unemployment level (\%);

9. Retail turnover per capita (RUB);

10. The amount of people who do regular exercises and sport per 1000 of population;

11. The amount of recorded offence per 100000 of population;

12. Fixed capital expenditure per capita (RUB).

Based on the diagnostic set of indicators, the assessment of competitiveness of the Republic of Tatarstan's municipalities was performed.

To assess and standardize the indicators, the point rating method was used, where the total score was received by the way of summing weighted grades on separate indicators.

To determine the weight of every indicator, we applied benchmark method using correlation coefficient. The method originally substantiates the overall index, and then every indicator is compared with it with the help of Spearman correlation coefficient:

$$
\rho=\frac{6 \sum d_{i}^{2}}{n^{3}-n}
$$

Then the highest correlation coefficient is defined $\left(r_{k}\right)$ and the weighting coefficient is calculated $\gamma_{i}$.

$\gamma_{i}=r_{i} / r_{k}$

GTP per capita was selected as the overall index, being the most common and significant parameter, which characterizes economic activity of the region.

The five-grade scale was used for assessment. For every indicator reference points were defined. The distance between them was divided into five sections. Depending on which of the sections the rated value belonged to, it was assigned from 1 to 5 points. For negative indices the inverse scale was used.

\section{Result}

Every municipality within the Republic of Tatarstan was given a score, according to which it was ranked.

Table 1. Composite scores for municipalities

\begin{tabular}{|c|c|c|c|c|c|}
\hline Region & Composite score & Region & Composite score & Region & Composite score \\
\hline Agryzsky & 11,8 & Vysokogorsky & 11,5 & Novosheshminsky & 11,8 \\
\hline Aznakayevsky & 12,2 & Drozhanovsky & 10,7 & Nurlatsky & 13,4 \\
\hline Aksubayevsky & 11,1 & Elabuzhsky & 16,6 & Pestrechinsky & 11 \\
\hline Aktanyshsky & 13,2 & Zayinsky & 11,7 & Rybno-Slobodsky & 10,7 \\
\hline Alexeevsky & 9,23 & Zelenodolsky & 12,6 & Sabinsky & 9,5 \\
\hline Alkeesky & 10,9 & Kaybitsky & 11,5 & Sarmanovsky & 12,3 \\
\hline Almetevsky & 21 & Kamsko-Us'insky & 9,95 & Spassky & 10,1 \\
\hline Apastovsky & 12,3 & Kukmorsky & 13 & Tetushsky & 10,6 \\
\hline Arsky & 12,8 & Layishevsky & 13,4 & Tukayevsky & 13,4 \\
\hline Atnynsky & 11,4 & Leninogorsky & 12,5 & Tulachinsky & 12,5 \\
\hline Bavlinsky & 11,9 & Mamadyshsky & 10,5 & Cheremshansky & 12,1 \\
\hline Baltasynsky & 10,9 & Mendeleevsky & 10,5 & Chistopolsky & 11,4 \\
\hline Bugulminsky & 13 & Menzelinsky & 10,2 & Utazinsky & 13,1 \\
\hline Buinsky & 13,7 & Muslumovsky & 11,1 & & \\
\hline Verkhneuslonsky & 11 & Nizhnekamsky & 18,7 & & \\
\hline
\end{tabular}

Municipalities of the Republic of Tatarstan received the score from 9,23 to 20,95 points. Three regions had more than 16 points - Almetyevsky $(20,95)$, Nizhnekamsky $(18,73)$ and Elabuzhsky $(16,61)$. These are the three leading regions, the results of which are well ahead of other municipalities (Fig. 1). Almetyevsky and Nizhnekamsky regions gained the highest score by most rates.

Other regions can hardly be grouped basing on the composite score, but they can be relatively divided into three groups.

The first group contains the regions ranked from 4 to 15. Though these regions are behind the leaders, they still surpass the regions behind them and are well ahead of the regions with the lowest scores. These are Aktanyshsky, 
Arsky, Bugulminsky, Buinsky, Zelenodolsky, Kukmorsky Layishevsky, Leninogorsky, Nurlatsky, Tukayevsky, Tulachinsky and Utazinsky regions.

The second group contains the regions ranked from 16 to 27. These are Agryzsky, Aznakayevsky, Apastovsky, Atninsky, Bavlinsky, Vysokogorsky, Zayinsky, Kaybitsky, Kukmorsky,Novosheshminsky, Sarmanovsky, Cheremshansky and Chistopolsky regions.

In the third group there are regions with the score from 28 to 43 . These are the remaining regions. Alexeevsky and Sabinsky districts stand out sufficiently among other regions, having scored the least points $(9,23$ and 9,5$)$. These two districts are well behind even the third group of regions.

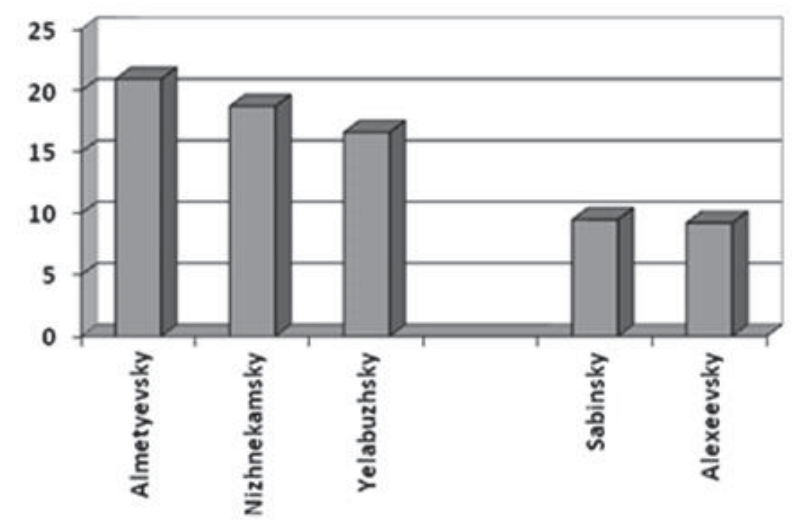

Figure 1. The leading and outsider regions.

The division into groups is very relative, as it is difficult to determine their clear boundaries. Only three leading regions and two regions with the lowest score distinguish significantly.

\section{The Conclusion}

The analysis showed that there is no region with the maximal score in all parameters. Furthermore, almost all regions have problems with one of the parameters in the rating. Thus, the second-ranked Nizhnekamsky region, with the highest score on economic parameters, received only one point on two parameters. This is connected with high indicator value of morbidity rate and the amount of crimes committed.

In many cases high economic performance is combined with high pollutant emission. These are mainly urban regions and regions near big cities. These municipalities also have the highest crime rate.

On the basis of the composite score obtained, the positioning of municipalities in the Republic of Tatarstan can be performed. Also, an indirect assessment of competitiveness of their economic complexes can be carried out as well as the detection of existing social and economic problems.

\section{References}

Huggins, R., Izushi, H., Prokop, D., Thompson, P. Regional evolution and waves of growth: A knowledge-based perspective // Expert Systems with Applications. 41(12), 2014, pp. 5573-5586.

Zhang, K.H. How does foreign direct investment affect industrial competitiveness? Evidence from China // China Economic Review. 30, 2014, pp. 530-539.

Ženka, J., Novotný, J., Csank, P. Regional Competitiveness in Central European Countries: In Search of a Useful Conceptual Framework // European Planning Studies. 22 (1), 2014, pp. 164-183.

Komarova, V.N., Zjablova, O.V., Denmukhametov, R.R. An infrastructure factor in regional competitiveness // Mediterranean Journal of Social Sciences. 5 (18 SPEC. ISSUE), 2014, pp. 355-360.

Enright M.I. The Geographical Scope of Competitive Advantage //Stuck in the Region? Changing scales for regional identity. - Utrecht, 1993. - P.87-102.

Porter M.E. The Competitive Advantage of Nations //Harvard Buisness Review. March - April, 1990. - P.73-93.

Denmukhametov, R.R. and O.V. Zjablova,. Geodemographic situation in the Republic of Tatarstan. World Applied Sciences Journal. Volume 30, Issue 11, 2014, pp. 1684-1688.

Gabdrakhmanov N.K. and M.V. Rozhko Positioning of Volga Federal District Regions by Demographic Situation Index // World Applied 
Sciences Journal, Volume 30 Number 6, 2014. pp. 792-795.

Gabdrakhmanov, N.K. and V.A. Rubtzov, 2014. Geodemographic Polarization Processes: Municipal Level (The Case of the Kukmorsky Municipal District of the Republic of Tatarstan). World Applied Sciences Journal, 30(10), pp. 1317-1320.

Bagautdinova, N., I. Gafurov, N., Kalenskaya and A. Novenkova, 2012. The regional development strategy based on territorial marketing (the case of Russia) World Applied Sciences Journal, 18. SPL.ISSUE., 18, pp. 179-184.

Gabdrakhmanov N.K., Rubtzov V.A., Shabalina S.A., Rozhko M.V., Kucheryavenko D.Z The role of territorial organization of cities in the touristic attraction of the region on the example of the Republic of Tatarstan // Life Science Journal 2014;11(11), pp. 451-455.

Mingaleva, Z., Bunakov, O. Innovative ways of using the tourist potential as the basis of territories development // Life Science Journal. Volume 11, Issue 6 SPEC. ISSUE, 2014, pp. 315-317. 